\title{
CARBON BALANCE IN FOREST MINERAL SOILS IN LATVIA MODELLED WITH YASSO07 SOIL CARBON MODEL
}

\author{
Andis Bārdulis, Ainārs Lupiḳis, Jeḷena Stola \\ Latvian State Forest Research Institute 'Silava' \\ andis.bardulis@silava.lv
}

\begin{abstract}
Yasso07 soil carbon model was used to estimate soil carbon balance in dry forest site types (6 site types in total) in Latvia and the results were compared with data from Biosoil2012 soil surveys. Litter input, chemical quality and climatic data are required to run the model. Three different scenarios were used for climate data input - steady climate, climate change $+0.025^{\circ} \mathrm{C}$ annually and climate change $+0.05^{\circ} \mathrm{C}$ annually.

Forest mineral soil is a carbon sink for the whole modelled period - the years of $1990-2030$. Under steady climate, the average carbon removal is $0.6 \mathrm{t} \mathrm{CO}_{2} \mathrm{ha}^{-1} \mathrm{yr}^{-1}$, under climate change $\left(+0.025{ }^{\circ} \mathrm{C}\right)$ scenario $0.4 \mathrm{t} \mathrm{CO}_{2} \mathrm{ha}^{-1} \mathrm{yr}^{-1}$, but under climate change $\left(+0.05^{\circ} \mathrm{C}\right)$ scenario $0.3 \mathrm{t} \mathrm{CO}_{2} \mathrm{ha}^{-1} \mathrm{yr}^{-1} . \mathrm{CO}_{2}$ removal at the beginning of the period (1990) was $0.35-0.38 \mathrm{t} \mathrm{CO}_{2} \mathrm{ha}^{-1} \mathrm{yr}^{-1}$. Carbon stock modelled with Yasso07 is lower than estimated in Biosoil2012 soil surveys. Differences between modelled and Biosoil2012 results vary from $2 \mathrm{t} \mathrm{C} \mathrm{ha}^{-1}$ in the poorest and $41 \mathrm{t} \mathrm{CO}_{2}$ ha $^{-1}$ in the third poorest site type. Carbon stock modelled with Yasso07 increases from the poorest to the most fertile site type while Biosoil2012 shows an increase from the poorest to the third poorest, and a decrease from the third poorest to the most fertile site type. Underestimation and different trends between Yasso07 and measured carbon stock may be explained by inappropriate equations and models used to estimate non-woody biomass. It is necessary to improve accuracy of input data for non-woody biomass by elaborating national equations and models in order to include Yasso07 in the national GHG inventory.
\end{abstract}

Key words: carbon, mineral soil, forest, modelling.

\section{Introduction}

Soil is one of the largest terrestrial carbon pools (Schimel, 1995; Schlesinger \& Andrews, 2000). One third to fifth of the total soil carbon pool is stored in organic soils (Gorham, 1991; Yu et al., 2010), the rest in mineral soils. It is estimated that approximately two thirds of terrestrial carbon pool in the long term are involved in active interaction between the atmosphere and soil (Post et al., 1982), and more carbon is stored in soil than is present in the atmosphere (Davidson \& Janssens, 2006). Thus, alterations in this cycle may accelerate rates of global warming. Furthermore, the temperature increase may intensify fluxes of carbon from soil (Cox et al., 2000; Wieder, Bonan, \& Allison, 2013).

A large proportion of carbon stored in mineral soils is in forest ecosystems (Pan et al., 2011), especially in high latitudes (Dixon et al., 1994). Although the importance of forest mineral soils to a global carbon cycle is high, it is not mandatory to report emissions from forest mineral soils in the National Greenhouse Gas Inventory. This is related to the complexity of those processes and lack of data (Buchholz et al., 2014).

The whole carbon cycling in forest ecosystem is not complete if soil carbon is not included. Some of the forestry practices may contribute to climate change mitigation through a higher energy wood production, for example, stump removal or removals of residues during harvesting (Lazdins \& Mattila, 2012). At the same time, it may negatively impact soil carbon storage (Kataja-aho et al., 2012).
There are several factors which significantly affect the soil carbon balance. It is worth mentioning such abiotic factors as temperature (Schimel et al., 1994; Trumbore, Chadwick, \& Amundson, 1996), moisture (Davidson, Belk, \& Boone, 1998), soil texture (Richter et al., 1999; Krull, Baldock, \& Skjemstad, 2003) and more complicated biotic factors as microbial activity (Wieder et al., 2013). Moreover, the interaction between those factors may significantly change intensity and direction of impact for each of those factors. Usually soil temperature rise causes increased $\mathrm{CO}_{2}$ fluxes from soil (Schimel et al., 1994; Trumbore et al., 1996). But if the temperature rise interacts with drought, it may significantly reduce $\mathrm{CO}_{2}$ emissions (Grünzweig et al., 2009; Dato et al., 2009; Joos et $a l ., 2010)$. The complexity of impact of those factors limits the possibility to elaborate simple and reliable emission factors for mineral soil in greenhouse gas inventory. In order to solve the problem, soil carbon models can be used.

There are several models available to model soil carbon cycling in mineral soils, including Yasso07 soil carbon model. Yasso07 is a dynamic soil carbon model, created specifically for forest mineral soils (Liski et al., 2005). The impact of main climatic variables, such as temperature and precipitation, is considered in the model. One of the advantages of Yasso07 against other models is its simplicity. Input data can be easily measured or calculated from measured data.

Yasso07 model is used in this study to calculate the carbon balance in forest mineral soil at a national scale. The aim is to estimate the soil carbon balance in 
dry forest site types in Latvian forests with Yasso07 soil carbon model and to evaluate the applicability to include results in the national greenhouse gas inventory.

\section{Materials and Methods}

Yasso07 is a dynamic soil carbon model. The model can be used for different mineral soils worldwide and it is not limited by climatic or geographic conditions (Liski et al., 2005; Tuomi et al., 2011). Litter input data, climate data and initial state of soil are necessary to run the model.

Litter input is formed by dead wood which is accounted directly in NFI and from living biomass. The average growing stock diameter data for each forest type of dry site type forests was used to calculate the total above and below ground living biomass. The data was collected from the National Forest Inventory (NFI). According to the Latvian forest classification system, there are 6 forest types under dry site type forests which represent dry mineral soils, ranked from the least to the most fertile: cladinoso-callunosa $(\mathrm{Cl})$, vacciniosa (Va), myrtillosa (My), hylocomiosa (Hy), oxalidosa (Ox), aegopodiosa (Ae) (Zālītis \& Jansons, 2013).

The growing stock is in $\mathrm{m}^{3} \mathrm{ha}^{-1}$ units. Biomass conversion factors created by LSFRI Silava were used to convert from volume to above- (stem, branches) and below-ground (stumps, roots) biomass units in tons (unpublished). Biomass in foliage and bark was calculated using biomass equations created by Repola (Repola, Ojansuu, \& Kukkola, 2007; Repola, 2009). Fine root biomass was calculated depending on the tree species, from the results published by Finer et $a l$. (2011). It was assumed that fine root biomass is dependent only on the tree species. The respective fine root biomass per hectare values is $3.38 \mathrm{tC} \mathrm{ha}^{-1}$ for pine and spruce and $3.20 \mathrm{t} \mathrm{Cha}^{-1}$ for deciduous trees.

It was assumed that litter production from living biomass is linear and proportional to the total biomass of each group of biomass. Coefficients of litter production rates are shown in Table 1. These litter production rates are created in Finland for boreal forests (Lehtonen et al., 2004; Starr et al., 2005; Liski et al., 2006).
Tree species are divided in three classes: pine, spruce and deciduous. Rates for deciduous trees are originally created for birch, but they are used for other deciduous species too.

Litter input from ground vegetation is $0.506 \mathrm{t} \mathrm{C}^{\mathrm{Ca}} \mathrm{yr}^{-1}$ for myrtillosa and hylocomiosa site types. The source of this value is Finnish national greenhouse gas emission inventory, the litter production rate of ground vegetation for southern Finland. The ground vegetation litter production in cladinoso-callunosa, vacciniosa, oxalidosa and aegopodiosa site types is, respectively, 0.5, 0.75, 1.25 and 1.5 times of $0.506 \mathrm{t} \mathrm{C} \mathrm{ha}^{-1} \mathrm{yr}^{-1}$.

Fallen and cut down trees are accounted directly in NFI and this is also a source of litter. All tree stems that have been fallen or cut down (including stumps of those trees) and left in the forest are accounted for as coarse woody litter (diameter $>10 \mathrm{~cm}$ ). Other compartments are fine woody $(<10 \mathrm{~cm})$ or non-woody biomass. Biomass of different groups of biomass of fallen or cut down trees was calculated using the same biomass equations as for living biomass.

Considerable litter input is produced from cut down and removed trees. Although stems have been removed from the forest, stumps and roots are left for decomposition. It is assumed that also $50 \%$ of branches are left in the forest, others are removed as biofuel.

Yasso07 requires input data for chemical quality of litter input. Chemical quality is divided into 4 classes according to the solubility of organic compounds in different solvents - acid soluble, water soluble, ethanol soluble and non-soluble (Table 2). There are 5 different groups of litter. The data about quality of different groups of litter are from Yasso07 user manual (Liski, Tuomi, \& Rasinmaki, 2009).

Zero level was chosen for the initial state (no carbon in soil), because of land use history in Latvia. Vast areas of forest historically were agricultural lands which were afforested later. That is why the trend of carbon stock in soil should be increasing over the past century. The model was run for 200 years for calibration purposes. The input data of 1990s was used for calibration.

\section{Table 1}

\section{Annual litter production rates proportionally to biomass of different groups of biomass}

\begin{tabular}{|l|c|c|c|c|c|c|}
\hline $\begin{array}{c}\text { Litter production } \\
\text { rates }\end{array}$ & Needles & Branches & Bark of stems & Bark of stumps & Roots >2mm & Fine roots \\
\hline Pine & 0.25 & 0.020 & 0.0052 & 0.0029 & 0.018 & 0.85 \\
\hline Spruce & 0.10 & 0.013 & 0.0027 & 0.0000 & 0.013 & 0.85 \\
\hline Deciduous & 0.79 & 0.014 & 0.0029 & 0.0001 & 0.014 & 0.85 \\
\hline
\end{tabular}


Annual litter production rates proportionally to biomass of different groups of litter

Table 2

\begin{tabular}{|l|l|l|l|l|l|}
\hline \multirow{2}{*}{ Groups of litter } & \multicolumn{1}{|c|}{ Tree species } & \multicolumn{1}{c|}{ Acid soluble } & Water soluble & Ethanol soluble & Non soluble \\
\hline \multirow{5}{*}{ Stem } & pine & 0.67 & 0.03 & 0.01 & 0.29 \\
\cline { 2 - 6 } & spruce & 0.67 & 0.02 & 0.01 & 0.31 \\
\cline { 2 - 6 } & deciduous & 0.7 & 0.02 & 0.01 & 0.28 \\
\hline \multirow{3}{*}{ Branches } & pine & 0.46 & 0.02 & 0.08 & 0.43 \\
\cline { 2 - 6 } & spruce & 0.67 & 0.02 & 0.01 & 0.31 \\
\cline { 2 - 6 } & deciduous & 0.7 & 0.02 & 0.01 & 0.28 \\
\hline \multirow{5}{*}{ Fine roots } & pine & 0.58 & 0.13 & 0.06 & 0.23 \\
\cline { 2 - 6 } & spruce & 0.55 & 0.13 & 0.07 & 0.25 \\
\cline { 2 - 6 } & deciduous & 0.43 & 0.2 & 0.1 & 0.27 \\
\hline \multirow{5}{*}{ Foliage } & pine & 0.52 & 0.18 & 0.09 & 0.22 \\
\cline { 2 - 6 } & spruce & 0.48 & 0.13 & 0.07 & 0.32 \\
\cline { 2 - 6 } & deciduous & 0.43 & 0.2 & 0.1 & 0.27 \\
\hline Vegetation & all & 0.27 & 0.47 & 0.23 & 0.03 \\
\hline
\end{tabular}

Three different scenarios were used for climate input data. The first scenario is steady climate. Interannual climatic data were used for this scenario. The average temperature is $+5.9^{\circ} \mathrm{C}$, precipitation $667 \mathrm{~mm}$ and monthly temperature variation $-7.8^{\circ} \mathrm{C}$. The second is climate change scenario. It was assumed that the annual raise of temperature is $+0.025^{\circ} \mathrm{C}$ since 1990 in this scenario. The third scenario is climate change with $+0.05{ }^{\circ} \mathrm{C}$ annually. In both climate change scenarios interannual data is used until 1990.

Results of Yasso07 were compared with results from the forest soil inventory in 2012. Soil inventory throughout the country was done within Biosoil soil surveys in 2006 and 2012. Soil samples down to $80 \mathrm{~cm}$ soil profile were collected with soil volumetric sampler to estimate soil dry bulk density and carbon content.

Mean organic carbon stock in $\mathrm{m}^{3}$ ha $\mathrm{h}^{-1}$ was calculated from Biosoil data for 5 of 6 forest site types in dry mineral soils. No data was available for the most fertile site type - Aegopodiosa. In total, all 55 sample plots representing forests on dry mineral soil in Biosoil were used in calculation, respectively, 3, 5, 13, 21 and 13 sample plots for cladinoso-callunosa, vacciniosa, myrtillosa, hylocomiosa and, oxalidosa.

\section{Results and Discussion}

Under the steady climate scenario, the forest mineral soil is a stable carbon sink. The model shows carbon removals for the whole 1990 - 2030 period. High peaks and changes since 2009 are related to the availability of NFI data. This is the time when the first NFI cycle was completed in 2008 and the second cycle of NFI was started and more accurate information about tree biomass changes and dead wood production was available. The average NFI data values were extrapolated for the period before. The average $\mathrm{CO}_{2}$ removals for steady climate scenario are $\sim 0.6 \mathrm{t} \mathrm{CO}_{2} \mathrm{ha}^{-1} \mathrm{yr}^{-1}$. Removals vary from $0.2 \mathrm{t} \mathrm{CO}_{2} \mathrm{ha}^{-1}$ to $1.0 \mathrm{t} \mathrm{CO}_{2} \mathrm{ha}^{-1} \mathrm{yr}^{-1}$ (Figure 1). Even if the climate change is considered, forest mineral soil still acts as a sink not source of $\mathrm{CO}_{2}$. Under the most severe climate change scenario $\left(+0.05^{\circ} \mathrm{C}\right.$ annually), soil is a source of $\mathrm{CO} 2$ only for one year. All other time the forest mineral soil is $\mathrm{CO}_{2}$ sink $\left(0.1-0.7 \mathrm{t} \mathrm{CO}_{2} \mathrm{ha}^{-1} \mathrm{yr}^{-1}\right)$.

De Wit et al. (2006) reports $0.29 \mathrm{t} \mathrm{CO}_{2} \mathrm{ha}^{-1} \mathrm{yr}^{-1}$ for year 1990 in Norway, also modelled by Yasso07, which is slightly lower compared to our results $0.38 \mathrm{t} \mathrm{CO}_{2} \mathrm{ha}^{-1} \mathrm{yr}^{-1}$. Almost similar results to Wit et al. (2006) are also reported by Rantakari et al. (2012) for Finnish forest mineral soil $0.27 \mathrm{t} \mathrm{CO}_{2} \mathrm{ha}^{-1} \mathrm{yr}^{-1}$. Higher removals in our study can be explained by land use history. Our forests are relatively young. During the last century, the total area and growing stock in Latvian forests have doubled. The increase originates from afforestation of grasslands and croplands, which generally have a lower soil carbon stock.

The results are highly sensitive to carbon input data. Especially, the variation of total carbon input through woody biomass (Thürig et al., 2005). It is concluded by Thürig et al. (2005) that the removal of fallen trees after strong windthrows may turn soil from sink to source. Our study shows that there is strong correlation between changes in total carbon input in soil and changes in net carbon balance $(r=0.98)$. The peaks in $\mathrm{CO}_{2}$ balance correlate with peaks in litter input. The smallest estimated litter input is in 2010 when the lowest $\mathrm{CO}_{2}$ removals have been modelled, while the highest $\mathrm{C}$ input is in 2014 , followed by the highest $\mathrm{CO}_{2}$ removals. 

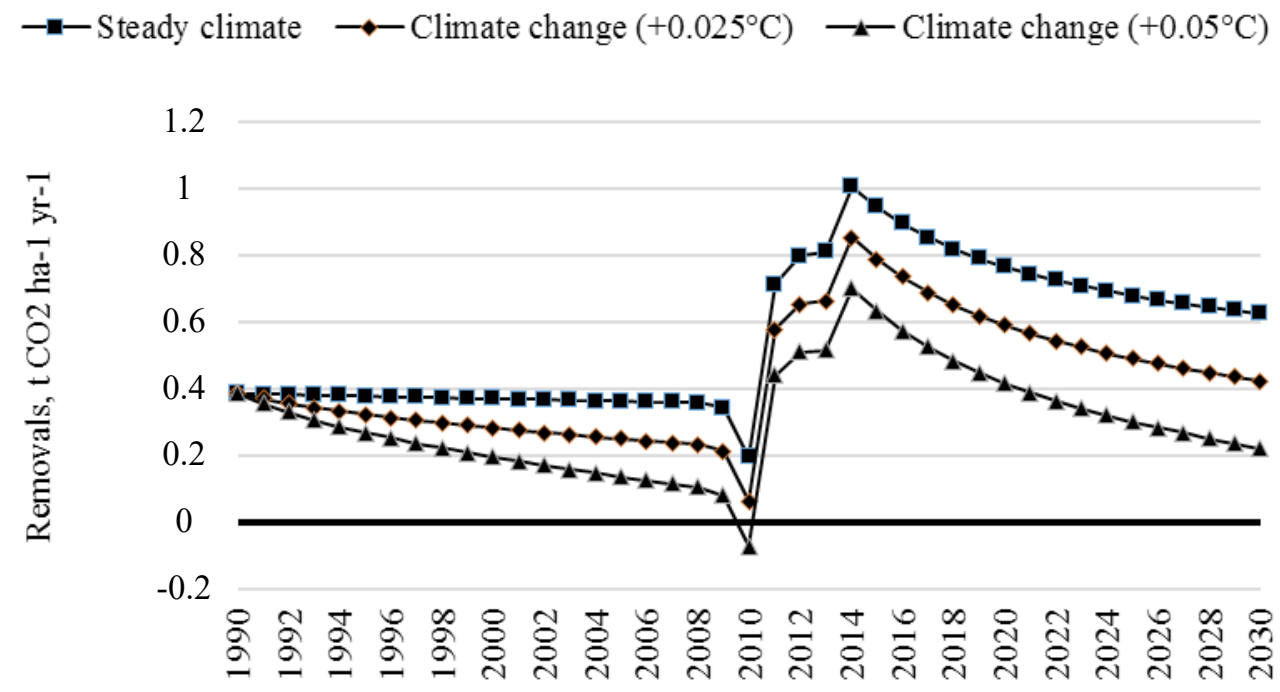

Figure $1 . \mathrm{CO}_{2}$ net removals in forest mineral soils.

If the average forest productivity per area unit will keep increasing or stay at the current level, litter production rate also should increase or stay at the current level. And forest mineral soil will be carbon sink also for the next two decades. It is not projected that mineral soil in forest may turn to a carbon source even under climate change. Furthermore, it is predicted that climate change and following temperature increase and longer vegetation season may accelerate tree growth (Jansons et al., 2013, 2014, 2015).

Carbon stock modelled with Yasso07 (in 2012, steady climate scenario) was compared with data from Biosoil soil surveys to evaluate the modelled results (Figure 2). The trend is to underestimate carbon stock with Yasso07. In 5 of the 6 (no data for the most fertile site type in Biosoil) dry site forest types the carbon stock is smaller with Yasso07 compared to inventory results from Biosoil. There are only slight differences in the poorest cladinoso-callunosa site type and the second most fertile oxalidosa site type $\left(6 \mathrm{t} \mathrm{Cha}^{-1} \mathrm{yr}^{-1}\right.$ and $\left.2 \mathrm{t} \mathrm{C} \mathrm{ha-}^{-1} \mathrm{yr}^{-1}\right)$. For those site types, with average fertility, differences are bigger, with the biggest for the third poorest site type myrtillosa $\left(42 \mathrm{t} \mathrm{C} \mathrm{ha}^{-1} \mathrm{yr}^{-1}\right)$.

Results modelled with Yasso07 show an increasing trend in carbon stock from the poorest towards the most fertile site type, with the least carbon stock in the poorest cladinoso-callunosa site type and the biggest carbon stock in the most fertile site aegopodiosa. This trend is not present in Biosoil surveys. Biosoil shows an increasing trend from the poorest to the third poorest site type. Then the trend is getting opposite and carbon stock is decreasing from the third poorest to the most fertile site type.

Carbon stock modelled by Yasso07 strongly correlates with the total carbon input data. The highest average carbon input is in the aegopodiosa site type (most fertile) and is $76 \%, 56 \%, 41 \%, 25 \%$ and $20 \%$ higher than the other site types ranked from the poorest to most fertile (Table 3). Carbon input is the main factor influencing carbon stock in different forest types. Biosoil results highlight the impact of other factors, also influencing carbon storage in soil. Organic matter decomposition in fertile soils is usually faster than in poor soils. This is partly driven by vegetation differences between fertile and poor site types. Vegetation in fertile forests is dominated by deciduous trees and herbs in the ground vegetation, compared to coniferous trees, mosses and lichens in poor sites. Theoretically, the impact of type of vegetation on carbon cycling should be excluded by chemical composition data input in Yasso07. However, there is a lack of reliable input data for non-woody biomass, which is the main carbon input pool. There is almost no information about the ground vegetation biomass dynamic among forest types and vegetation types for Latvian forests. The share of total carbon input through ground vegetation is $8 \%-12 \%$. Furthermore, the biggest pool for carbon carbon input is fine roots $(40 \%-70 \%$ of total input), but this is the most uncertain pool at the same time. Additional errors may be caused by unsuitable non-woody tree litter production rates for our conditions $(8 \%-20 \%$ of total input). Litter production rates are calculated based on studies from boreal vegetation zone.

Overall, the share of non-woody biomass to the total carbon stock is $70 \%$, of which the share of ground vegetation, fine roots and non-woody litter is, respectively, $15 \%, 9 \%$ and $46 \%$. Considerable contribution to carbon cycling shows the necessity for more accurate input data for those pools. Currently, there are no suitable models or equations elaborated for local conditions to calculate carbon input to soil from non-woody biomass. All input data, except fine roots, for non-woody biomass have been calculated 


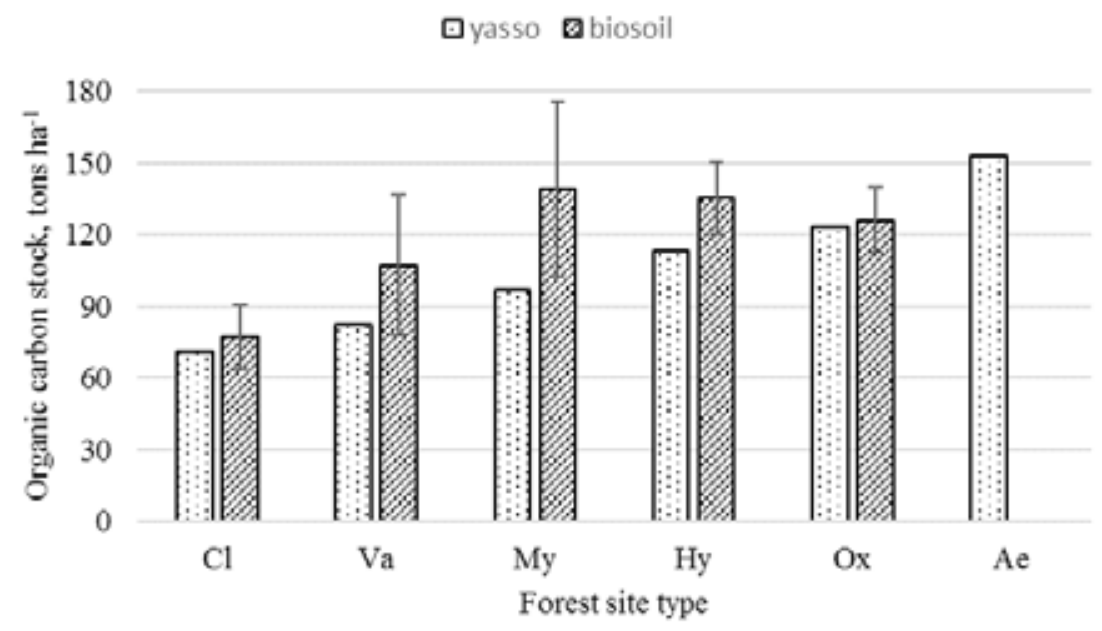

Figure 2. Organic carbon stock in different forest site types (Error bars shows $1 \mathrm{SE}, \mathrm{Cl}$ - cladinoso-callunosa, Va - vacciniosa, My - myrtillosa, Hy hylocomiosa, Ox - oxalidosa, Ae - aegopodiosa).

Carbon input in soil by different groups of biomass and forest site types

Table 3 (all given values are in tons $\mathrm{ha}^{-1} \mathrm{yr}^{-1}$ )

\begin{tabular}{|l|l|l|l|l|l|l|}
\hline \multicolumn{1}{|c|}{} & \multicolumn{1}{|c|}{$\mathrm{Cl}$} & \multicolumn{1}{c|}{$\mathrm{Va}$} & \multicolumn{1}{c|}{$\mathrm{My}$} & \multicolumn{1}{c|}{ Ox } & Ae \\
\hline Coarse woody biomass $(>10 \mathrm{~cm})$ & 0.03 & 0.06 & 0.17 & 0.28 & 0.56 & 0.79 \\
\hline Woody biomass $(<10 \mathrm{~cm})$ & 0.23 & 0.38 & 0.46 & 0.73 & 0.57 & 0.80 \\
\hline Non-woody biomass & 3.43 & 3.74 & 4.00 & 4.18 & 4.30 & 4.91 \\
\hline Total & 3.68 & 4.18 & 4.62 & 5.20 & 5.44 & 6.50 \\
\hline
\end{tabular}

using data from boreal vegetation zone. Fine root data reported by Finer et al., (2011) are compiled from literature for boreal, temperate and tropical forests. Still, the data are rough and with a high uncertainty as may be expected if the global datasets are used.

\section{Conclusions}

Soil at dry forest site types is a carbon sink. Soil will continue to sequester carbon at least for the next two decades even under changing climate. Results with Yasso07 show underestimation of carbon stock when comparing modelled results with measured ones in Biosoil2012 soil survey. There are also different trends between site types among fertility gradient. Yasso07 shows an increasing trend from the poorest to the most fertile site, while there is no such a trend in Biosoil2012. These inconsistencies may be explained by inappropriate non-woody biomass input data. In order to include Yasso07 in the Latvian national GHG inventory, national models or equations should be developed to estimate the litter production from nonwoody biomass pool.

\section{Acknowledgments}

The study is done within the scope of the project funded by the Ministry of Environment protection and regional development "Calculations of direct and indirect GHG emissions in 2014 for land use, land use change and forestry sector and recalculation of GHG emissions in 1990 - 2013 according to guidelines of Intergovernmental Panel of Climate Change and obligations under United Nations Framework Convention on Climate Change, Kyoto protocol and European Parliament and Comission decision No. 25/2013 and 749/2014" (No. 2015/13).

\section{References}

1. Buchholz, T., Friedland, A.J., Hornig, C.E., Keeton, W.S., Zanchi, G., \& Nunery, J. (2014). Mineral soil carbon fluxes in forests and implications for carbon balance assessments. GCB Bioenergy. 6 (4), $305-311$. DOI: $10.1111 /$ gcbb.12044.

2. Cox, P.M., Betts, R.A., Jones, C.D., Spall, S.A., \& Totterdell, I.J. (2000). Acceleration of global warming due to carbon-cycle feedbacks in a coupled climate model. Nature. 408, 184-187. DOI: 10.1038/35041539. 
3. Dato, G.D. de, Angelis, P.D., Sirca, C., \& Beier, C. (2009). Impact of drought and increasing temperatures on soil CO2 emissions in a Mediterranean shrubland (gariga). Plant and Soil. $327(1-2), 153$ - 166. DOI: 10.1007/s11104-009-0041-y.

4. Davidson, E.A., Belk, E., \& Boone, R.D. (1998). Soil water content and temperature as independent or confounded factors controlling soil respiration in a temperate mixed hardwood forest. Global Change Biology. 4 (2), 217 - 227. DOI: 10.1046/j.1365-2486.1998.00128.x.

5. Davidson, E.A., \& Janssens, I.A. (2006). Temperature sensitivity of soil carbon decomposition and feedbacks to climate change. Nature. 440, 165 - 173. DOI: 10.1038/nature04514.

6. de Wit, H.A., Palosuo, T., Hylen, G., \& Liski, J. (2006). A carbon budget of forest biomass and soils in southeast Norway calculated using a widely applicable method. Forest Ecology and Management. 225 (1 - 3), 15 - 26. DOI: 10.1016/j.foreco.2005.12.023.

7. Dixon, R.K., Solomon, A.M., Brown, S., Houghton, R.A., Trexier, M.C., \& Wisniewski, J. (1994). Carbon Pools and Flux of Global Forest Ecosystems. Science. 263, 185 - 190. DOI: 10.1126/science.263.5144.185.

8. Finér, L., Ohashi, M., Noguchi, K., \& Hirano, Y. (2011). Factors causing variation in fine root biomass in forest ecosystems. Forest Ecology and Management. 261 (2), 265-277. DOI: 10.1016/j.foreco.2010.10.016.

9. Gorham, E. (1991). Northern Peatlands: Role in the Carbon Cycle and Probable Responses to Climatic Warming. Ecological Applications. 1 (2), 182 - 195. DOI: 10.2307/1941811.

10. Grünzweig, J.M., Hemming, D., Maseyk, K., Lin, T., Rotenberg, E., Raz-Yaseef, N., \& Yakir, D. (2009). Water limitation to soil $\mathrm{CO} 2$ efflux in a pine forest at the semi-arid "timberline." Journal of Geophysical Research. 114, G03008.

11. Jansons, A., Matisons, R., Lībiete-Zālīte, Z., Baders, E., \& Rieksts-Riekstiņš, R. (2013). Relationships of Height Growth of Lodgepole Pine (Pinus contorta var. latifolia) and Scots Pine (Pinus sylvestris) with Climatic Factors in Zvirgzde, Latvia. Baltic Forestry, 19 (2), 236 - 244.

12. Jansons, A.., Matisons, R., Zadina, M., Sisenis, L., \& Jansons, J. (2015). The effect of climatic factors on height increment of Scots pine in sites differing by continentality in Latvia. Silva Fennica. 49 (3), 14. DOI: 10.14214/sf.1262.

13. Jansons, A., Zeps, M., Rieksts-Riekstins, J., Matisons, R., \& Krisans, O. (2014). Height increment of hybrid aspen Populus tremuloides x P. tremula as a function of weather conditions in south-western part of Latvia. Silva Fennica. 48 (5), 13.

14. Joos, O., Hagedorn, F., Heim, A., Gilgen, A.K., Schmidt, M.W.I., Siegwolf, R.T.W., \& Buchmann, N. (2010). Summer drought reduces total and litter-derived soil CO2 effluxes in temperate grassland - clues from a 13C litter addition experiment. Biogeosciences. 7 (3), 1031 - 1041. DOI: 10.5194/bg-7-1031-2010.

15. Kataja-aho, S., Smolander, A., Fritze, H., Norrgård, S., \& Haimi, J. (2012). Responses of soil carbon and nitrogen transformations to stump removal. Silva Fennica. 46 (2). DOI: 10.14214/sf.53.

16. Krull, E.S., Baldock, J.A., \& Skjemstad, J.O. (2003). Importance of mechanisms and processes of the stabilisation of soil organic matter for modelling carbon turnover. Functional Plant Biology. 30 (2), 207 222. DOI: 10.1071/fp02085.

17. Lazdins, A., \& Mattila, M. (2012). Evaluation of results of forest regeneration after stump extraction in Finland. In Research for Rural Development. Annual 18th International Scientific Conference Proceedings. Jelgava, Latvia: Latvia University of Agriculture.

18. Lehtonen, A., Sievänen, R., Mäkelä, A., Mäkipää, R., Korhonen, K.T., \& Hokkanen, T. (2004). Potential litterfall of Scots pine branches in southern Finland. Ecological Modelling. 180 (2 - 3), 305 - 315. DOI: 10.1016/j.ecolmodel.2004.04.024.

19. Liski, J., Lehtonen, A., Palosuo, T., Peltoniemi, M., Eggers, T., Muukkonen, P., \& Mäkipää, R. (2006). Carbon accumulation in Finland's forests 1922 - 2004 an estimate obtained by combination of forest inventory data with modelling of biomass, litter and soil. Annals of Forest Science. 63 (7), 11. DOI: 10.1051/forest:2006049.

20. Liski, J., Palosuo, T., Peltoniemi, M., \& Sievänen, R. (2005). Carbon and decomposition model Yasso for forest soils. Ecological Modelling. 189 (1 - 2), 168 - 182. DOI: 10.1016/j.ecolmodel.2005.03.005.

21. Liski, J., Tuomi, M., \& Rasinmaki, J. (2009). Yasso07 user-interface manual (p. 14). Helsinki: Finnish Environment Institute. Retrieved February 10, 2017, from: file://C:/Users/pc/Downloads/Yasso07_userinterface\%20manual.pdf.

22. Pan, Y., Birdsey, R.A., Fang, J., Houghton, R., Kauppi, P.E., Kurz, W.A., ... Hayes, D. (2011). A Large and Persistent Carbon Sink in the World's Forests. Science. 333, 988 - 993. DOI: 10.1126/science.1201609.

23. Post, W.M., Emanuel, W.R., Zinke, P.J., \& Stangenberger, A.G. (1982). Soil carbon pools and world life zones. Nature. 298, 156 - 159. DOI: 10.1038/298156a0. 
24. Rantakari, M., Lehtonen, A., Linkosalo, T., Tuomi, M., Tamminen, P., Heikkinen, J., ... Sievänen, R. (2012). The Yasso07 soil carbon model - Testing against repeated soil carbon inventory. Forest Ecology and Management. 286, 137 - 147. DOI: 10.1016/j.foreco.2012.08.041.

25. Repola, J. (2009). Biomass equations for Scots pine and Norway spruce in Finland. Silva Fennica. 43 (4), $625-647$.

26. Repola, J., Ojansuu, R., \& Kukkola, M. (2007). Biomass functions for Scots pine, Norway spruce and birch in Finland. Working papers of Finnish Forest Research Institute. 53. Retrieved February 16, 2017, from: http://www.metsantutkimuslaitos.fi/julkaisut/workingpapers/2007/mwp053.pdf.

27. Richter, D.D., Markewitz, D., Trumbore, S.E., \& Wells, C.G. (1999). Rapid accumulation and turnover of soil carbon in a re-establishing forest. Nature. 400, 56 - 58. DOI: 10.1038/21867.

28. Schimel, D.S. (1995). Terrestrial ecosystems and the carbon cycle. Global Change Biology. 1 (1), 77 - 91. DOI: $10.1111 /$ j.1365-2486.1995.tb00008.x.

29. Schimel, D.S., Braswell, B.H., Holland, E.A., McKeown, R., Ojima, D.S., Painter, T.H., ... Townsend, A.R. (1994). Climatic, edaphic, and biotic controls over storage and turnover of carbon in soils. Global Biogeochemical Cycles. 8 (3), 279 - 293. DOI: 10.1029/94GB00993.

30. Schlesinger, W.H., \& Andrews, J.A. (2000). Soil respiration and the global carbon cycle. Biogeochemistry. 48 (1), 7 - 20. DOI: 10.1023/A:1006247623877.

31. Starr, M., Saarsalmi, A., Hokkanen, T., Merilä, P., \& Helmisaari, H.-S. (2005). Models of litterfall production for Scots pine (Pinus sylvestris L.) in Finland using stand, site and climate factors. Forest Ecology and Management. 205 (1 - 3), 215 - 225. DOI: 10.1016/j.foreco.2004.10.047.

32. Thürig, E., Palosuo, T., Bucher, J., \& Kaufmann, E. (2005). The impact of windthrow on carbon sequestration in Switzerland: a model-based assessment. Forest Ecology and Management. 210 (1 - 3), 337 - 350. DOI: 10.1016/j.foreco.2005.02.030.

33. Trumbore, S.E., Chadwick, O.A., \& Amundson, R. (1996). Rapid exchange between soil carbon and atmospheric carbon dioxide driven by temperature change. Science. 272 (5260). 393 - 396. DOI: 10.1126/ science.272.5260.393.

34. Tuomi, M., Rasinmäki, J., Repo, A., Vanhala, P., \& Liski, J. (2011). Soil carbon model Yasso07 graphical user interface. Environmental Modelling \& Software. 26 (11), 1358 - 1362. DOI: 10.1016/j. envsoft.2011.05.009.

35. Wieder, W.R., Bonan, G.B., \& Allison, S.D. (2013). Global soil carbon projections are improved by modelling microbial processes. Nature Climate Change. 3 (10), 909 - 912. DOI: 10.1038/nclimate1951.

36. Yu, Z., Loisel, J., Brosseau, D.P., Beilman, D.W., \& Hunt, S.J. (2010). Global peatland dynamics since the Last Glacial Maximum. Geophysical Research Letters. 37 (13), L13402. DOI: 10.1029/2010GL043584.

37. Zālītis, P., \& Jansons, J. (2013). Latvijas meža tipologija un tās sākotne (Latvian forest typology and its origin). Daugavpils: Daugavpils universitātes akadēmiskais apgāds Saule. (in Latvian). 